\title{
Purification and Properties of an ATPase from Sulfolobus solfataricus ${ }^{1}$
}

\author{
Lawrence I. Hochstein ${ }^{* .2}$ and Helga Stan-Lotter ${ }^{*} \dagger$ \\ *Ames Research Center, Moffett Field, California 94035; and †The SETI Institute, Mountain View, California 94043
}

Received October 10,1991, and in revised form January 17,1992

\begin{abstract}
A sulfite-activated ATPase isolated from Sulfolobus solfataricus had a relative molecular mass of 370,000 . It was composed of three subunits whose relative molecular masses were $63,000,48,000$, and 24,000 . The enzyme was inhibited by the vacuolar ATPase inhibitors nitrate and $N$-ethylmaleimide; 4 -chloro- 7 -nitrobenzofurazan (NBD-Cl) was also inhibitory. $N$-Ethylmaleimide was predominately bound to the largest subunit while NBD-Cl was bound to both subunits. ATPase activity was inhibited by low concentrations of p-chloromercuriphenyl sulfonate and the inhibition was reversed by cysteine which suggested that thiol groups were essential for activity. While the ATPase from $S$. solfataricus shared several properties with the ATPase from $S$. acidocaldarius there were significant differences. The latter enzyme was activated by sulfate and chloride and was unaffected by $\boldsymbol{N}$-ethylmaleimide, whereas the $S$. solfataricus ATPase was inhibited by these anions as well as $N$-ethylmaleimide. These differences as well as differences that occur in other vacuolar-like ATPases isolated from the methanogenic and the extremely halophilic bacteria suggest the existence of several types of archaeal ATPases, none of which have been demonstrated to synthesize ATP. (c) 1992 Academic Preas, Inc.
\end{abstract}

$\mathrm{F}_{10} \mathrm{~F}_{1}$ and vacuolar ATPases are membrane-bound proton translocating enzymes. The $F_{0} F_{1}$ ATPases are associated with bacterial cytoplasmic membranes, mitochondrial membranes, and thylakoids, where they function as ATP synthases. The vacuolar ATPases are located on the endomembranes of eukaryotic cells, where they hydrolyze ATP and generate gradients of protons that are subsequently used to transport solutes into intracellular vacuoles. These enzymes are also differentiated on the basis

\footnotetext{
1 This work was supported with funds from the NASA Exobjology Program to L.1.H. on the early evolution of life which in turn supported Cooperative Agreement NCC2-578 through The SETI Institute to H.S.

"To whom correspondence should be addressed.
}

of the sensitivity of vacuolar ATPases to nitrate, NEM, ${ }^{3}$ and the antibiotic bafilomycin (1), agents that do not affect $F_{0} F_{1}$ ATPases. In addition, the enzymes' subunits differ with respect to their number and relative molecular masses (for recent reviews of $F_{0} F_{1}$ and vacuolar ATPases see Refs. (2) and (3), respectively). Although the amino acid sequences of the largest of the subunits of $F_{0} F_{1}$ and vacuolar ATPases suggest that they are related, the overall identity is low (4).

Archaeal ATPases are structurally unlike $F_{01} F_{1}$ ATPases. The catalytic portion consists of from two to five subunits (5-9) whose relative molecular masses are considerably higher than are those for the analogous subunits from $F_{0} F_{1} A T P a s e s$. In addition, there is no evidence for the presence of a membrane component equivalent to the $F_{0}$ moiety, although in the case of Sulfolobus acidocaldarius a low molecular mass DCCD-reactive proteolipid (10) exhibits considerable amino acid sequence homology with subunit $c$ from $F_{0} F_{1}$ ATPases (11). The amino acid sequence of the $\alpha$ and $\beta$ subunits of the ATPases from Methanosarcina barkeri (5) and $S$. acidocaldarius (12), and the two major subunits from the ATPase from Halobacterium salinarium (13) display considerable homology with sequences from subunits $B$ and $A$, respectively, of vacuolar ATPases (14) which suggests that these enzymes are more closely related to vacuolar rather than $F_{0} F_{1}$ ATPases. On the other hand, antiserum prepared against the $\beta$ subunit of the ATPase from $S$. acidocaldarius crossreacts with the $\beta$ subunit from various $F_{0} F_{1}$ ATPases as well as subunit II from $H$. saccharovorum (9).

The ATPases from $H$. saccharovorum and $H$. salinarium (formerly designated $H$. halobium) are similar with respect to the relative molecular masses of the native enzymes

\footnotetext{
${ }^{3}$ Abbreviations used: DCCD, dicyclohexylcarbodiimide; NEM, $N$ ethylmaleimide; NBD-Cl, 4-chloro-7-nitrobenzofurazan (or 4-chloro-7. nitrobenzo-2-oxa-1,3-diazole); PA(GE, polyacrylamide gel electrophoresis; PCMS, $p$-chloromercuriphenyl sulfonate: SDS, sodium dodecyl sulfate; Caps. 3-(cyclohexylamino)propanesulfonic acid; PMSF, phe nylmethylsulfonvl fluoride; seph 6B, Sepharose $6 \mathrm{BB}$
} 
and their two major subunits $(6,15)$. Their sensitivity to nitrate and NEM suggests that they may be vacuolar ATPases (16). However, the situation in the halobacteria is complicated in that these ostensibly similar ATPases differ in several significant properties (17). An analogous situation exists in the case of $S$. acidocaldarius, where two ATPases have been described which possess very different properties $(8,18)$. We recently purified an ATPase from $S$. solfataricus whose several properties suggest that this enzyme is yet another type of Sulfolobus ATPase. We wish to report on these observations, suggest that they are consistent with the notion that there may be a multiplicity of Archaeal vacuolar-like ATPases, and emphasize that none has been demonstrated to synthesize ATP (i.e., act as an ATP synthase).

\section{MATERIALS AND METHODS}

Growth and preparation of cell-free extracts. Sulfolobus strain $98 / 2$ was obtained from $T$. Langworthy and identified as $S$. solfataricus (N. Pace, personal communication). It was grown at $70^{\circ} \mathrm{C}$ in a medium consisting of the following additions (in grams per liter of deionized water): ( $\left.\mathrm{NH}_{4}\right)_{2} \mathrm{SO}_{4}(1.3), \mathrm{MgSO}_{4} \cdot 7 \mathrm{H}_{2} \mathrm{O}$ (0.25), $\mathrm{CaCl}_{2} \cdot 2 \mathrm{H}_{2} \mathrm{O}$ (0.07), $\mathrm{KH}_{2} \mathrm{PO}_{4}(0.28)$, L-glutamic acid (0.5), and yeast extract (1.0). The $\mathrm{pH}$ was adjusted at room temperature to 3.2 with $5 \mathrm{~N}$ sulfuric acid. The medium was autoclaved for $15 \mathrm{~min}$ at $20 \mathrm{psi}$ and after it had cooled, sterile glucose was added to a final concentration of $0.2 \%(w / v)$. Cells were grown in a three-necked 3 -liter round bottom flask containing 2 liters of medium. The flask, which was placed in a heating mantle, had a condenser connected to one of the outlets; a gas dispersion tube fitted with a coarse glass-fritted cylinder was connected to the second outlet for the purposes of aerating the culture; and the third outlet was closed and used as a sampling port. The culture was vigorously aerated with sterile air which was first passed through a gas scrubler containing sterile watter using a Cole Palmer Air Cadet vacuum/pressure pump operated at 3 psi. The cells were harvested after the culture entered the stationary phase (ca. $54 \mathrm{~h}$ ) by centrifuging at $5900 \mathrm{~g}$ for $30 \mathrm{~min}$ at $4^{\circ} \mathrm{C}$. The cells were suspended in $\mathrm{pH} 7.1$ Buffer $\mathrm{A}(20 \mathrm{mM} \mathrm{Na}-\mathrm{Hepes} / 10 \mathrm{mM}$ $\mathrm{MgCl}_{2} / 6 \mathrm{mM} \mathrm{NaN} / 200 \mu \mathrm{M}$ PMSF) to a buffer/cell ratio of 8 (vol/wet wt) and passed through a cold $\left(\mathrm{ca}, 4^{\circ} \mathrm{C}\right)$ French pressure cell operated at $12,000 \mathrm{psi}$. After cent rifuging at $5900 \mathrm{~g}$ for $30 \mathrm{~min}$ at $4^{\circ} \mathrm{C}$, the resulting supernatant was centrifuged at 245,000$)$ f for 1 h at $4^{\circ} \mathrm{C}$. The supernatant was decanted and designated the soluble fraction. The sediment was made up in Butfer $\mathrm{A}$ and designated the membrane fraction.

Assays. ATPase activity was determined at $86^{\circ} \mathrm{C}$ by following the release of $P_{1}$. The reaction mixture contained the following additions (in micromoles) in a total volume of $1 \mathrm{ml}$ : $\mathrm{Na}$-Hepes $\mathrm{pH} 6.6$ buffer prepared at $86^{\circ} \mathrm{C}(50) ; \mathrm{MgCl}_{2}(6.25)$; ATP (12.5); and enzyme. The enzyme was incubated in the buffer for 2 min at $86^{\circ} \mathrm{C}$ before adding ATP (as the $\mathrm{Mg}$-ATP complex). The reaction was terminated by the addition of $1 \mathrm{ml}$ of cold $\left(4^{\circ} \mathrm{C}\right) 10 \%$ trichloroacetic acid and any precipitate was removed by cent rifugation at $3900 \mathrm{~g}$ for $10 \mathrm{~min}$ at $4^{\circ} \mathrm{C}$. When the protein concentration did not interfere with the $P$, determination (which was the case with the UG and Seph $6 \mathrm{~B}$ fractions) the reaction was terminated by adding $1 \mathrm{ml}$ cold $\left(4^{\circ} \mathrm{C}\right)$ water. Following the addition of water, the contents were kept at $4^{\circ} \mathrm{C}$ until assayed for $P_{1}$, which was determined by the method of LeBel et al. (19). The assay was linear for $15 \mathrm{~min}$ and up to the accumulation of $2 \mu \mathrm{mol}$ of $P_{i}$. Protein was determined by the bicinchoninic acid method (20).

Subunit labeling of NEM and NBI-Cl. The enzyme was labeled by adding $10 \mu \mathrm{l}$ of the Seph $6 \mathrm{~B}$ fraction $(90 \mu \mathrm{g})$ to $190 \mu \mathrm{l}$ of $50 \mathrm{mM} \mathrm{Na}$ Hepes butfer ( $\mathrm{pH} 7.2$ at room temperature) that contained either 140 $\mathrm{nmol} N-\left[2,3{ }^{14} \mathrm{C}\right]$ ethylmaleimide or $200 \mathrm{nmol}$ of $\left[\mathrm{U} \cdot{ }^{14} \mathrm{C}\right] \mathrm{NBD}-\mathrm{Cl}$. The mixtures were incubated for $30 \mathrm{~min}$ at room temperature and $2 \mathrm{~min}$ at $86^{\circ} \mathrm{C}$. Excess NEM and NBD-C 1 were removed using the procedure described by Penefsky (21). The enzyme was subsequently dissociated with SDS and the location of radioactivity determined following SDS PAGE.

Polyacrylamide gel electrophoresis. Analytical PAGE was performed at $\mathrm{pH} 8.9$ using Tris glycine buffer and $5 \%$ gels according to the method of Davis (22). Proteins were detected by staining the gels overnight with Coomassie blue. ATPase activity was located on the gels as a calcium phosphate precipitate (2:3) in the following manner. The gels were suspended in $50 \mathrm{mM} \mathrm{Na}$-Hepes buffer ( $\mathrm{pH} 6.6$ at room temperature) and incubated at room temperature for $15 \mathrm{~min}$. The gels were subsequently transferred into tubes that had been preincubated at $86^{\circ} \mathrm{C}$ and contained $50 \mathrm{mM} \mathrm{Na}-$ Hepes butfer $\left(\mathrm{pH} 6.6\right.$ at $\left.86^{\circ} \mathrm{C}\right)$ and $10 \mathrm{mM} \mathrm{CaCl} . \mathrm{Mg}-\mathrm{A}^{\prime} \mathrm{TP}$ was added to a final concentration $12.5 \mathrm{mM}$ and after about $15 \mathrm{~min}$ the enzyme was located by the appearance of a white band. A sample of the ATPase suitable for determining the subunit structure was obtained by electrophoresis of the Seph 613 fraction in several $5 \%$ gels. The enzyme was located by staining one gel for ATPase activity. Segments of the remaining gels corresponding to the location of the enzyme activity were macerated and extracted for $48 \mathrm{~h}$ at $4^{\circ} \mathrm{C}$ with Butfer $\mathrm{B}$. The gel fragments were sedimented by centrifugation at $10,000 \mathrm{~g}$ for $30 \mathrm{~min}$ at $4^{\circ} \mathrm{C}$. The supernatant was decanted and used to determine the subunit structure of the enzyme. SISS-PAGE was carried out with $11 \%$ gels as described by Laemmli (24). (iels containing isotopes were soaked in Amplify and dried under reduced pressure and the radioactivity was detected on Kodak XAR $5 \mathrm{film}$ by exposing the film at $-70^{\circ} \mathrm{C}$.

Determination of relatice molecular mass. The $M_{r}$ of the native en zyme was determined by gel filtration using a $1.5 \times 84-\mathrm{cm}$ UltroGe AcA34 column equilibrated in Buffer $B$. The following standards (with their $\left.M_{0}\right)$ were used: urease $(480,000)$, catalase $(232,000)$, aldolase $(157,000)$, bovine serum albumin, dimer and monomer $(134,000$ and $67,000)$, and ovalbumin $(45,(00))$. The $M_{r}$ of the subunits was determined by SDS-PAGE using the Sigma SDS- 70 low molecular weight kit standards.

Materials. $\mathrm{Na}_{2}$ ATP. $\mathrm{Na}$. ADP, PCMS, and the SDS-70 low mo lecular weight kit were obtained from the Sigma Chemical $\mathrm{Co}$. (St. Iouis. $\mathrm{MO}$ ). The $\mathrm{Na}_{2}-\mathrm{AI} \mathrm{P}^{3}$ contained $0.02 \%$ A'TP which represented a quantity whose hydrolysis would not be detected given the conditions we employed to assay for $P$, production. $N \cdot\left\{2,3 \cdot{ }^{14} \mathrm{C} \mid\right.$ Ethylmaleimide $(7 \mathrm{mC} / \mathrm{mmol})$ was obtained from Amersham Corp. (Arlington Heights, IL) while (U. ${ }^{24} \mathrm{C}$ |NBD-Cl $(109 \mathrm{mCi} / \mathrm{mmol})$ was purchased from Research Products International Corp. (Mount Prospect, IL). Hepes was obtained from Cal Biochem (La Julla, CA). Proteins were determined with reagents obtained from the Pierce Chemical Co. (Rockford, IL). The PD-10 de. salting columns and Centricon 30 microconcentrators were obtained from Pharmacia Fine Chemicals (Piscataway, NJ) and the Amicon Corp. (Lexington, MA), respectively. Ultru(iel AcA34 was a product of LKB Instruments, Inc. (Gaithersburg, MD).

\section{RESULTS}

\section{Purification of the Enzyme}

ATPase activity was present in the membrane and cytoplasmic fractions. This distribution was directly related to the force used to disrupt the cells. In addition, storage of the membranes at $4^{\circ} \mathrm{C}$ resulted in the gradual appearance of soluble ATPase activity and was associated with the concomitant loss of membrane-bound ATPase activity. Preliminary experiments indicated the membrane and soluble activities were similar with respect to their response to anions, inhibitors, and $\mathrm{pH}$ and temperature optima (K. Meier and I. I. Hochstein, unpublished data).

The enzyme in the soluble fraction was unstable and was immediately processed at least through the ammo- 
TABLE I

Purification of the S. SOLFATARICUS ATPase

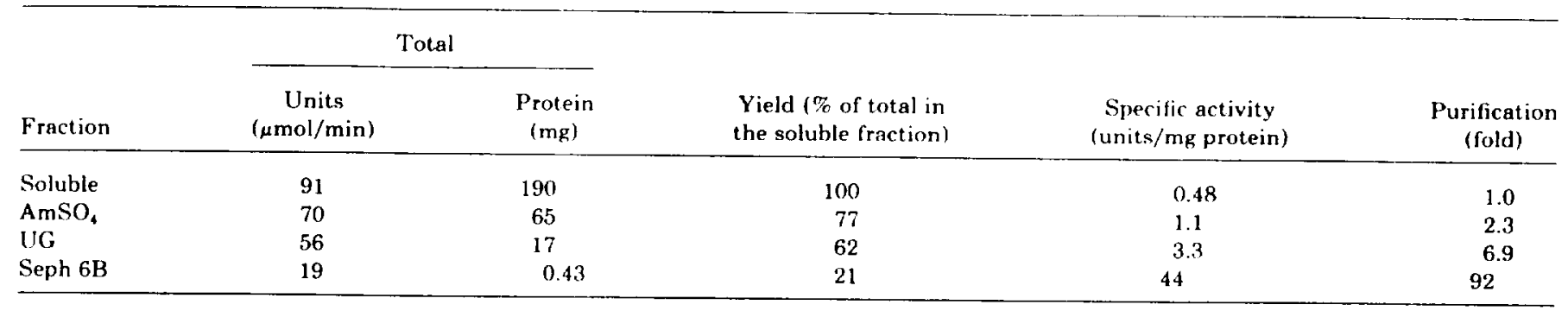

nium sulfate fractionation step. The soluble fraction was adjusted to a protein concentration of $4 \mathrm{mg} / \mathrm{ml}$ with Buffer $A$ and made $50 \%$ saturated with respect to ammonium sulfate. This mixture was stirred for $30 \mathrm{~min}$ at room temperature (ca. $22^{\circ} \mathrm{C}$ ) and then centrifuged at $10,000 \mathrm{~g}$ for $30 \mathrm{~min}$ at $22^{\circ} \mathrm{C}$. The sediment was made up to a protein concentration of about $12 \mathrm{mg} / \mathrm{ml}$ in Buffer A (AS fraction) and passed through an UltraGel AcA34 column $(1.5 \times 85$ $\mathrm{cm}$ ) equilibrated in $\mathrm{pH} 7.4$ Buffer $\mathrm{B}(20 \mathrm{mM}$ Hepes $/ 6 \mathrm{mM}$ $\left.\mathrm{NaN}_{3}\right)$. Those fractions that contained A'PPase activity $\left(V_{\mathrm{e}} / V_{0}=1.42\right)$ were combined and designated the UG fraction. The UG fraction was made $18 \%$ with respect to $\left(\mathrm{NH}_{4}\right)_{2} \mathrm{SO}_{4}$ and applied to a Sepharose $6 \mathrm{~B}$ column $(1.6 \times$ $29 \mathrm{~cm}$ ) previously equilibrated in Buffer $B$ that was also $18 \%$ with respect to $\left(\mathrm{NH}_{4}\right)_{2} \mathrm{SO}_{4}$. The column was washed with $100 \mathrm{ml}$ of $18 \%\left(\mathrm{NH}_{4}\right)_{2} \mathrm{SO}_{4} /$ Buffer $\mathrm{B}$ followed by a decreasing linear $\left(\mathrm{NH}_{4}\right)_{2} \mathrm{SO}_{4}$ gradient (18 to $6 \%$ ammonium sulfate in Buffer $\mathrm{B}$ over $200 \mathrm{ml}$ ). ATPase activity, which appeared between 13 and $11.5 \%\left(\mathrm{NH}_{4}\right)_{2} \mathrm{SO}_{4}$, was combined, passed through a PD-10 desalting column, concentrated in an Centricon 30 microconcentrator, and designated as the Seph $6 \mathrm{~B}$ fraction. The enzyme was stored at $4^{\circ} \mathrm{C}$ as it was unstable at $-19^{\circ} \mathrm{C}$ and lost approximately $80 \%$ of its initial activity within 2 days at that temperature.

Table I summarizes a typical purification of the soluble ATPase starting with $3.5 \mathrm{~g}$ of cells. In this particular case, $75 \%$ of the total activity was associated with the soluble fraction. The soluble fraction also contained an active pyrophosphatase, the bulk of which remained soluble in $50 \%$ ammonium sulfate and which did not adsorb to Sepharose 6B in the presence of $18 \%$ ammonium sulfate. Following hydrophobic chromatography on Sepharose $6 \mathrm{~B}$ and the removal of ammonium sulfate, the ATPase (i.e., the Seph $6 B$ fraction) hydrolyzed $44 \mu \mathrm{mol}$ of ATP $/ \mathrm{min} /$ $\mathrm{mg}$ of protein which represented a 92 -fold purification and a $21 \%$ recovery of the activity present in the soluble fraction. Once purified, the enzyme from $S$. solfataricus was extremely stable and could be stored at $4^{\circ} \mathrm{C}$ for at least 3 months with little loss of activity.

Several proteins were detected in the Seph $6 \mathrm{~B}$ fraction by PAGE. Only one, which corresponded to the major constituent, exhibited in situ ATPase activity in the gels.
To determine the subunit structure of the enzyme, the Seph 6B fraction was further "purified" by PAGE. For this experiment, 4.5 units of ATPase were subjected to PAGE and 3.2 units were subsequently recovered after extraction and concentration. The protein concentration following PAGE could not be determined as some component in the procedure interfered with the protein determination. The electrophoretically purified enzyme was composed of three subunits (Fig. 1a) whose $M_{r}$ were $63,000,48,000$, and 24,000 (Fig. 1b). This compares with values of $65,000,51,000$, and $20,000(9)$ and $69,000,54,000$, and $28,000(8)$ for the subunits from the $S$. acidocaldarius ATPase. The $M_{\mathrm{r}}$ of the native enzyme was 370,000 which was consistent with the $3: 3: 1$ subunit stoichiometry proposed for the $S$. acidocaldarius ATPase (18).

\section{Properties of the Enzyme}

As shown in Fig. 2, ATP hydrolysis took place most rapidly at $\mathrm{pH} 6.6$ when the enzyme was assayed at $86^{\circ} \mathrm{C}$ which was the temperature at which maximum ATPase activity occurred. There was no measurable activity at $30^{\circ} \mathrm{C}$. The enzyme exhibited an absolute requirement for

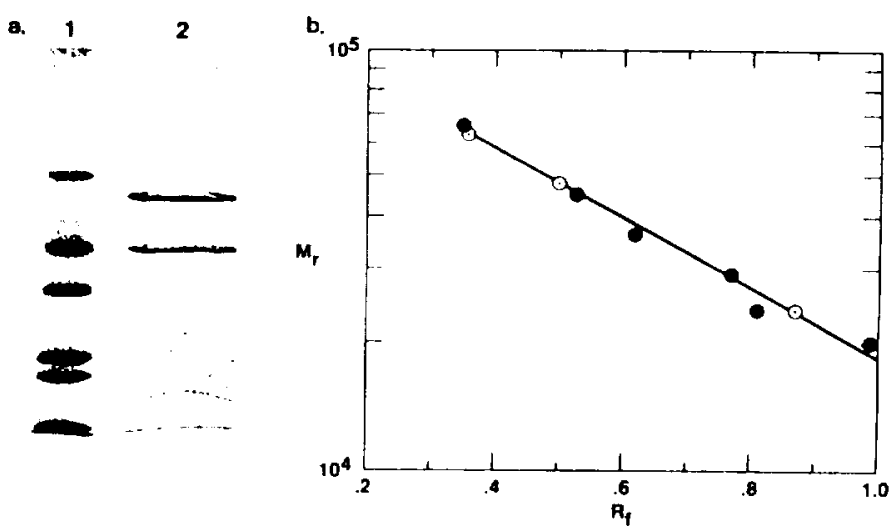

FIG. 1. Subunit structure of the $S$ solfataricus ATPase. The Seph $6 \mathrm{~B}$ fraction (100 $\mu \mathrm{g}$ protein) was "purified" hy PAGE and subsequently dissociated with SDS, and examined by SDS PAGE. (a) Lane 1, molecular mass standards; lane 2, Sulfolobus ATPase. (b) Relative mobility $\left(R_{f}\right)$ vs $\operatorname{lng} M_{r}$. 


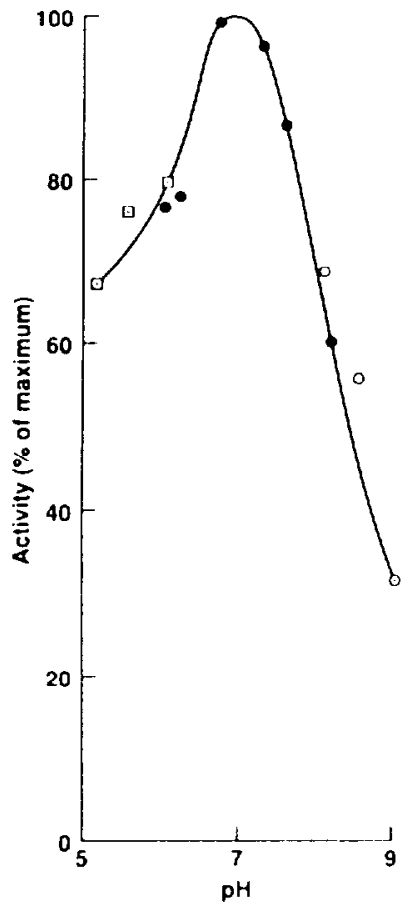

FIC. 2 . The effect of pH on A'l'lase activity. The Seph th fraction ( $2.5 \mu \mathrm{g}$ protein) was assayed in the presence of the following butfers which were adjusted to the desired $\mathrm{pH}$ at $86^{\circ} \mathrm{C}:$ Mes $(\square)$. Hepes $(\bullet)$, and Caps (O). $100 \%$ activity equals the production of $1.08 \mu \mathrm{mol} P_{1} / 10$ min.

a divalent cation. Magnesium and manganese were equally effective, whereas calcium was ineffective. ATPase activity increased with the $\mathrm{Mg} / \mathrm{ATP}$ ratio $(\mathrm{ATP}=12.5 \mathrm{mM}$ ), reaching a maximum between 0.25 and 0.5 ; higher ratios resulted in a marked inhibition of ATPase activity. An apparent $K_{m}$ of $0.6 \mathrm{mM}$ ATP was determined from Lineweaver-Burke plots $(\mathrm{Mg} / \mathrm{ATP}=0.5)$. The enzyme hydrolyzed the magnesium salts of $\mathrm{A}^{\prime} \mathrm{TP}, \mathrm{GTP}$, and ITP at approximately the same rate which was about 5 and 50 times the rates observed with the magnesium salts of UTP and CTP, respectively. The Seph $6 \mathrm{~B}$ fraction hydrolyzed $\mathrm{Mg}-\mathrm{ADP}$ and $\mathrm{MgP}_{4} \mathrm{O}_{7}$ at 9 and $<1 \%$ of the rate observed with Mg-ATP when assayed using conditions optimal for ATP hydrolysis. Since the Seph $6 B$ fraction contained several minor components, the portion of ADP hydrolyzing activity associated with the Sulfolobus was not certain. Mg-ADP also inhibited ATPase activity but determining a precise value for $K_{i}$ was complicated by the simultaneous hydrolysis of $\mathrm{Mg}-\mathrm{ADP}$. A $57 \%$ inhibition of ATPase activity was observed at ATP and ADP concentrations of 12.5 and $6.2 \mathrm{mM}$, respectively $(\mathrm{Mg} /$ nucleotides $=0.5)$. Plots of $1 / v$ versus $1 / S$ at different concentrations of ADP affected the slopes but not the intercepts indicating that $\mathrm{Mg}-\mathrm{ADP}$ was a competitive inhibitor with respect to $\mathrm{Mg}$-ATP.

\section{Effect of Anions}

ATPase activity was variously affected by anions (Fig. 3). Sulfite was stimulatory, with maximum activation taking place between 5 and $10 \mathrm{~mm}$ sulfite. Concentrations greater than $10 \mathrm{mM}$ sulfite resulted in a progressive decrease in the extent of activation and eventual inhibition of ATP hydrolysis. This was an effect not previously reported for the other Sulfolobus ATPases. Nitrate also inhibited the enzyme. A $50 \%$ inhibition occurred in the presence of $8 \mathrm{mM}$ nitrate, and $50 \mathrm{~mm}$ nitrate resulted in maximum inhibition (87\%) of ATPase activity. The enzyme was inhibited by sulfate. A $50 \%$ inhibition was produced by $25 \mathrm{mM}$ sulfate. The ATPase was inhibited by chloride although it was not too sensitive to that anion and was unaffected by $50 \mathrm{mM}$ sodium bicarbonate. Replacing sodium with ammonium ion had no significant effect on sulfate or chloride inhibition (data not shown). This suggests that the anion inhibition was neither quantitatively nor qualitatively related to the cation.

\section{Effect of Inhibitors}

The $S$. solfataricus ATPase was inhibited by NEM (Fig. 4 a), an alkylating reagent that reacts with sulfhydryl groups, although the reagent will react with amino residues when conditions are mildly alkaline (25). Maximum inhibition occurred between $500 \mathrm{mM}$ and $1 \mathrm{mM}$ NEM (Fig.

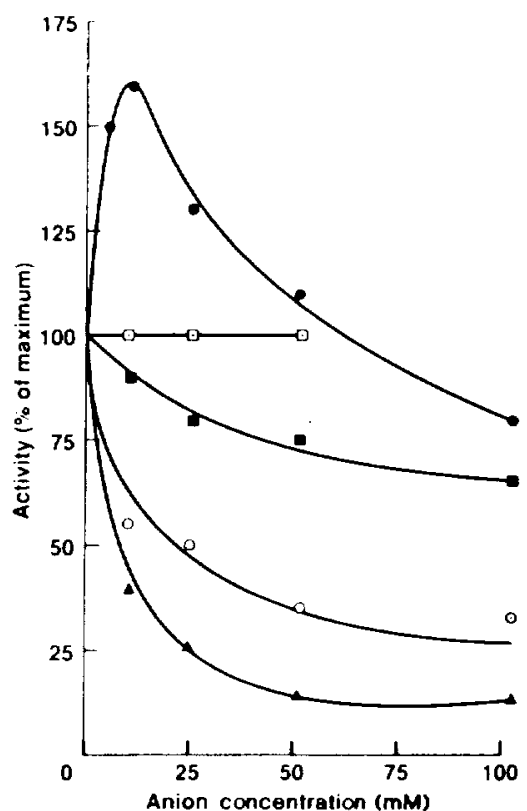

FIG. 3. Etfect of anions on ATPase activity. The Seph $6 \mathrm{~B}$ fraction (2.5 $\mu \mathrm{g}$ protein) was preincubated for 2 min at $86^{\circ} \mathrm{C}$ in the presence of the indicated concentrations of the sodium salts of sulfite $(O)$, bicarbonate $([)$, chloride $(\square)$, sulfate $(O)$, and nitrate $(\Delta)$ and subsequently assayed for ATPase activity. The results are reported as \% of the activity observed in the absence of added anions which was assigned a value of $100 \%$ and was equal to the production of $1.15 \mu \mathrm{mol} P / 10 \mathrm{~min}$. 

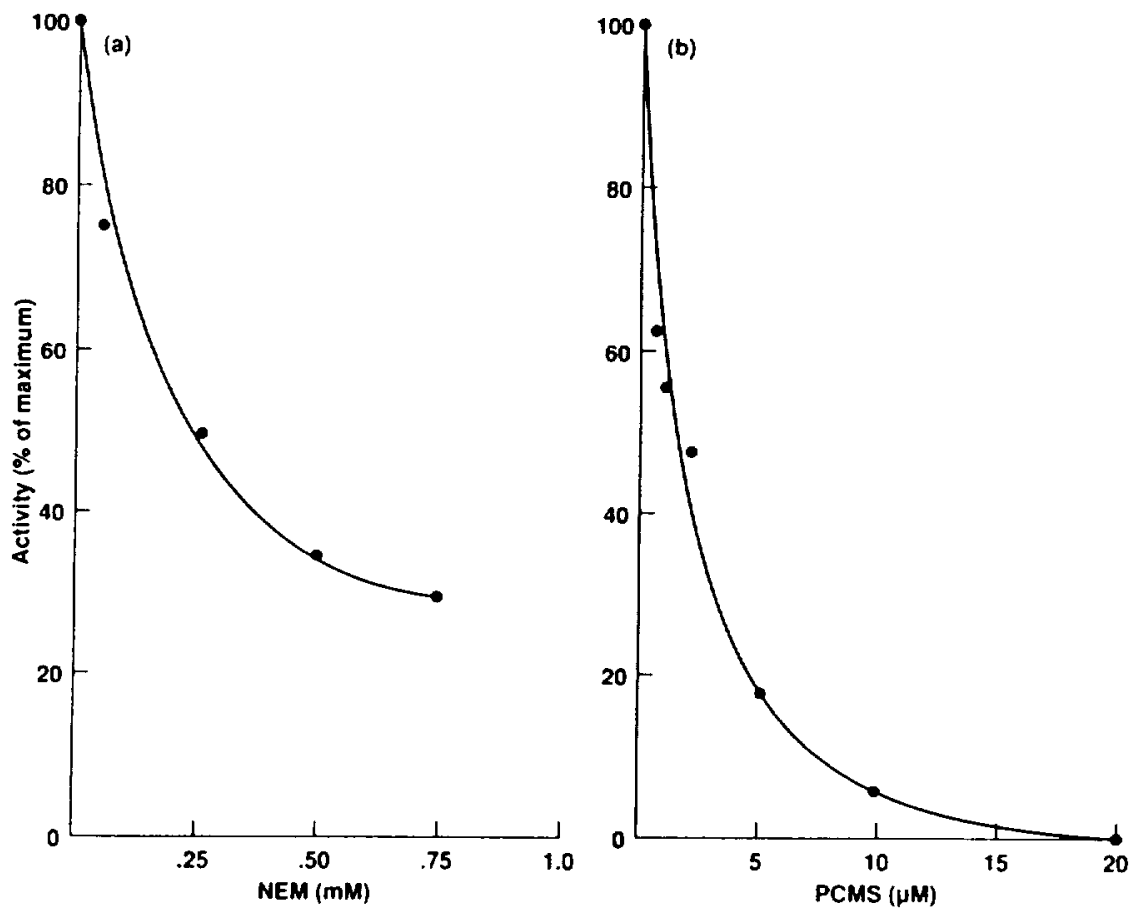

FIG. 4. Inhibition of ATPase activity by NEM and PCMS. The Seph $6 B$ fraction (2.5 $\mu$ g protein) was incubated at room temperature for 10 min in the presence of the indicated concentrations of NEM (a) or PCMS (b), after which the residual ATPase activity was determined. The results are reported as \% of the activity observed in the absence of added NEM or PCMS which was assigned a value of $100 \%$ and was equal to the production of $1.02 \mu \mathrm{mol} P_{\mathrm{i}} / 10 \mathrm{~min}$

4a). The enzyme was extremely sensitive to PCMS. As shown in Fig. 4b, 500 nM PCMS produced a $35 \%$ inhibition and enzyme activity was totally inhibited in the presence of $20 \mu \mathrm{M}$ PCMS. Preincubating the enzyme for $10 \mathrm{~min}$ in the presence of $5 \mu \mathrm{M}$ PCMS and subsequently for $2 \mathrm{~min}$ in the presence of $500 \mu \mathrm{M}$ cysteine reduced the inhibition from 88 to $8 \%$. The low concentrations of PCMS that inhibited the enzyme as well as the reversal of inhibition by cysteine were consistent with the involvement of thiols and by extension suggested that NEM also inhibited by reacting with thiol residues.

NBD-Cl inhibits $F_{0} F_{1}$ ATPases by reacting with a single tyrosinyl residue in the $\beta$ subunit, and the inhibition can be reversed by thiols (26). In the case of vacuolar ATPases the mode of action is not known and the inhibitor binds to a number of subunits. The ATPase from $S$. solfataricus was also inhibited by NBD-Cl. Preincubating the enzyme with $1 \mathrm{~mm} \mathrm{NBD}-\mathrm{Cl}$ for $15 \mathrm{~min}$ at $86^{\circ} \mathrm{C}$ inhibited ATPase activity $83 \%$ which was the maximum inhibition attained under these conditions (Fig. 5a). When the enzyme was preincubated at $86^{\circ} \mathrm{C}$ in the presence of $125 \mu \mathrm{M}$ NBD-Cl, the inhibition, which was $25 \%$ after $15 \mathrm{~min}$, was $77 \%$ after $2 \mathrm{~h}$ and appeared to continue to increase after that time (Fig. 5b). As also shown in Fig. 5b, the enzyme did not lose activity when incubated in buffer at $86^{\circ} \mathrm{C}$ for 120 min. As in the case of $F_{0} F_{1} A^{\prime}$ TPases (26), cysteine reversed NBD-Cl inhibition of the Sulfolobus ATPase. In addition, cysteine activated the enzyme. These effects are shown in Table II. The extent of reversal was inversely related to the time the enzyme was exposed to NBD-Cl. Virtually all the ATPase activity was recovered when the enzyme was first incubated with $250 \mu \mathrm{M} \mathrm{NBD}-\mathrm{Cl}$ for $15 \mathrm{~min}$ (which resulted in 52\% inhibition) and then $1 \mathrm{mM}$ cysteine for $10 \mathrm{~min}$. When the enzyme was incubated for $3 \mathrm{~h}$ with 250 $\mu \mathrm{M}$ NBD- $\mathrm{Cl}$ (which resulted in a $96 \%$ inhibition) before the addition of cysteine, $42 \%$ of the activity was recovered. This suggested the existence of at least two NBD-Cl derivatives of the enzyme, only one of which was reversed by cysteine, and recalled the behavior of NBD-Cl with $\mathrm{F}_{0} \mathrm{~F}_{1}$ ATPases (26). The presence of $\mathrm{Mg}$-ATP did not protect the Sulfolobus ATPase against NBD-Cl or NEM inhibition, which was unlike the ATPase from $H$. saccharovorum (16).

When the ATPase was incubated with $\left[{ }^{14} \mathrm{C} \mid \mathrm{NEM}\right.$ so that the enzyme was maximally inhibited, the bulk of the radioactivity was associated with the 63,000 -Da subunit with some radioactivity found with the 45,000 - and 24,000 Da subunits (Fig. 6). When the enzyme was incubated in the presence of $\left[{ }^{14} \mathrm{C}\right] \mathrm{NBD}-\mathrm{Cl}$, the inhibitor appeared to be the equally distributed between the two largest subunits (Fig. 6). It is not clear if this distribution reflected nonspecific interactions due to the reactive nature of NBD$\mathrm{Cl}(26)$ or if the high temperature during the assay exacerbated the reactivity and lack of specificity of NBD- 

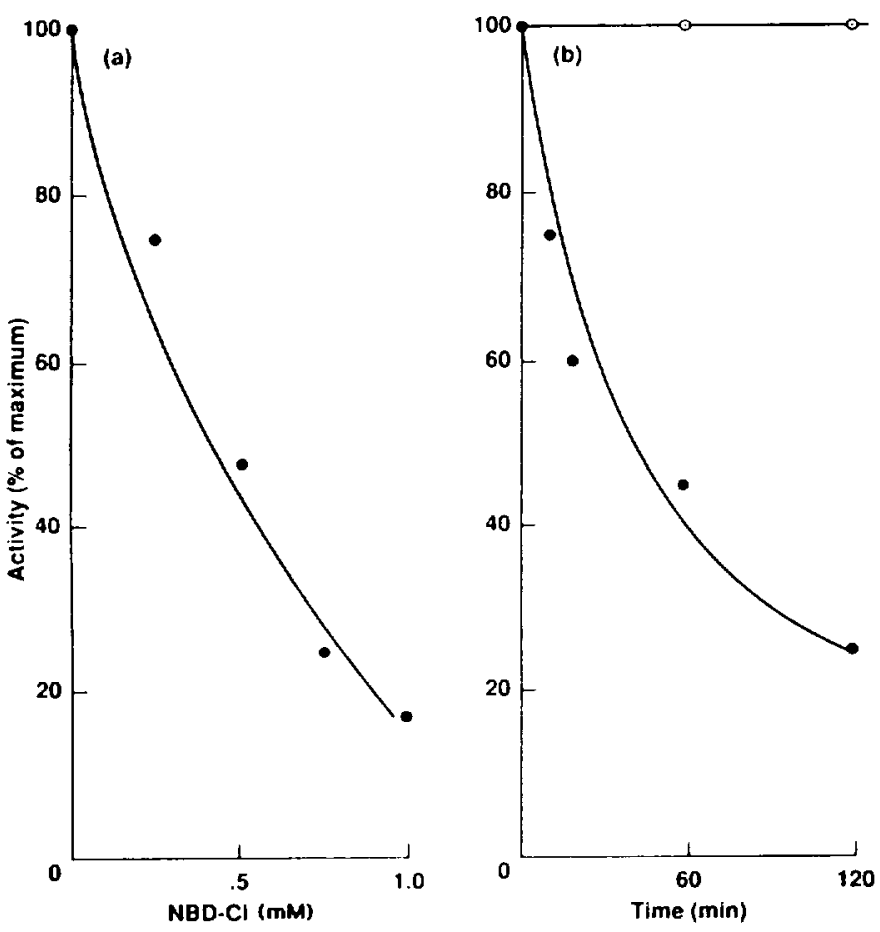

FIG. 5. Inhibition of ATPase activity by NBD-Cl. (a) The Seph $6 B$ fraction $\left(2.5 \mu \mathrm{g}\right.$ protein) was preincubated for $2 \mathrm{~min}$ at $86^{\circ} \mathrm{C}$ in the presence of the indicated concentrations of NBD- $\mathrm{Cl}$ and subsequently assayed for ATPase activity. (b) The effect of preincubation on inhibition. The enzyme was incubated at $86^{\circ} \mathrm{C}$ for the indicated times in the presence $(\bullet)$ and absence $(O)$ of $125 \mu \mathrm{M} \mathrm{NBD}-\mathrm{Cl}$ and assayed for residual ATPase activity as described under Materials and Methods. The results in both cases are reported as \% of the activity observed in the absence of added NBD-Cl, where $100 \%$ equals the production of 880 ninol of $P_{\mathrm{i}} / 10 \mathrm{~min}$.

$\mathrm{Cl}$ and resulted in intersubunit migration of the inhibitor subsequent to initial binding.

ATPase activity was not affected by azide $(10 \mathrm{mM})$, quercetin $(200 \mathrm{mM})$, or vanadate $(10 \mathrm{~mm})$. DCCD $(100$ $\mu \mathrm{M})$ was not inhibitory when incubated with the enzyme overnight at $\mathrm{pH} 6$ at room temperature $\left(22^{\circ} \mathrm{C}\right)$, conditions which inhibit the ATPase from $H$. saccharovorum and result in the binding of the inhibitor to subunit II (27).

\section{DISCUSSION}

The enzyme from $S$. solfataricus, like other archaeal ATPases, resembled vacuolar ATPases more than the $\mathrm{F}_{0} \mathrm{~F}_{1}$ ATPase. The $S$. solfataricus ATPase was inhibited by NEM and nitrate, and the number and the relative molecular masses of its subunits was more in character with vacuolar ATPases. In addition, NEM was bound to the largest of the Sulfolobus ATPase subunits, as is true with the ATPase from $H$. saccharovorum (Sulzner et al., manuscript in preparation) and vacuolar ATPases, which in the latter case is proposed to be the catalytic subunit $(28,29)$. However, unlike the vacuolar and halobacterial
TABLE II

Reversal of NBD-Cl Inhibition by Cysteine

\begin{tabular}{ccc}
\hline & \multicolumn{2}{c}{ Preincubation time } \\
\cline { 2 - 3 } Additions during preincubation & $15 \mathrm{~min}$ & $3 \mathrm{~h}$ \\
\hline Standard & 0.88 & 0.98 \\
+ NBD-Cl & 0.42 & 0.04 \\
+Cysteine & 1.51 & 1.54 \\
+ NBD-Cl/cysteine & 1.38 & 0.64 \\
\hline
\end{tabular}

Note. The Seph $6 \mathrm{~B}$ fraction ( $2.5 \mu \mathrm{g}$ protein) was preincubated in 50 $\mathrm{mM} \mathrm{Na-Hepes} \mathrm{buffer} \mathrm{at} \mathrm{room} \mathrm{temperature.} \mathrm{The} \mathrm{pH}$ of the buffer was 7.2 at room temperature and 6.6 at $86^{\circ} \mathrm{C}$. Where indicated, NBD-Cl $(250 \mu \mathrm{M})$ or cysteine $(1 \mathrm{mM})$ was present. After the indicated preincubation time, cysteine ( $1 \mathrm{mM}$ ) was added and after an additional $10 \mathrm{~min}$ at room temperature, the reaction mixtures were incubated for $2 \mathrm{~min}$ at $86^{\circ} \mathrm{C}$ and $\mathrm{Mg}-\mathrm{A}^{\prime} \mathrm{TP}$ was added to start the reaction. The results are presented as micromoles $P$, produced in $10 \mathrm{~min}$

ATPases, where the presence of ATP repressed NEM inhibition and decreased the incorporation of inhibitor, no substrate protection was observed in the case of the Sulfolobus enzyme.

The ATPase from $S$. solfataricus shared a number of properties with the $S$. acidocaldarius ATPase. The specific activities of the purified $S$. solfataricus and $S$. acidocaldarius (18) ATPases were similar; both ATPases were inhibited by similar concentrations of nitrate; and the relative molecular masses of the native enzymes and three of their subunits were in reasonable agreement. Recently, the enzyme from $S$. acidocaldarius was reported to contain a fourth subunit (9). Although we did not detect such a subunit, the composition of the $S$. solfataricus ATPase cannot be unequivocally established at this time. Proteolytic activity as well as the electrophoretic method used

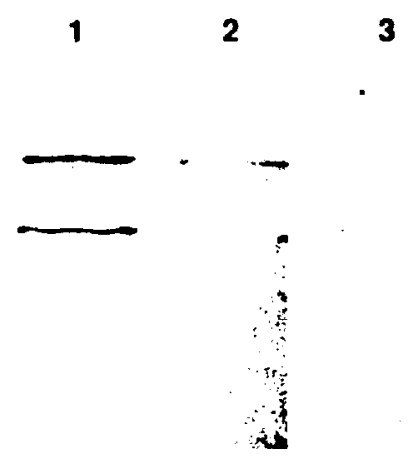

FIG. 6. $\left[{ }^{14} \mathrm{C} \mid N E M\right.$ and $\left[{ }^{14} \mathrm{C} \mid \mathrm{NBD}-\mathrm{Cl}\right.$ labeling of the $S$. sulfolobus ATPase. The Seph $6 \mathrm{~B}$ fraction was incubated with /'ClNEM or $\left[{ }^{14} \mathrm{C}\right] \mathrm{NBD} \cdot \mathrm{Cl}$ and subsequently subjected to SDS-PAGE as described under Materials and Methods. Eight micrograms of protein was applied to each lane. Lane 1, gel stained with Coomassie blue; lane 2, radioau. tograph following labeling with NEM; lane 3, radioautograph following labeling with NBD-CI 
to prepare the ATPase could have individually or collectively led to the loss of that subunit.

However, the Sulfolobus ATPases differ in ways to suggest they are not identical enzymes. Sulfate and chloride, which stimulate the ATPases from $S$. acidocaldarius, inhibit the $S$. solfataricus enzyme. Bicarbonate, which stimulates the enzyme from $S$. acidocaldarius, does not affect the ATPase from $S$. solfataricus. The Sulfolobus ATPases are also dissimilar with respect to their sensitivity to NEM and PCMS. The enzyme from the $S$. acidocaldarius is not significantly inhibited by NEM (8) and is considerably less sensitive to mercurials (18) than is the ATPase from $S$. solfataricus. The enzymes also differ with respect to their $\mathrm{pH}$ optima. In the absence of sulfite, the $S$. acidocaldarius ATPase exhibits acidic and alkaline maxima with a minimum at approximately $\mathrm{pH} 6.5$. The addition of sulfite to the enzyme isolated by Lübben $e t$ al. (18) results in a single and relatively broad maximum ( $\mathrm{pH} 5.5$ to 7.0 ) with a $300 \%$ increase in enzyme activity. This stimulation is due to the increase in activity at the $\mathrm{pH}$ minimum. There is no stimulation at the alkaline $\mathrm{pH}$ maximum and only a $20 \%$ enhancement at the acidic $\mathrm{pH}$ maximum. The addition of sulfite to the ATPase described by Konishi $e t$ al. (8) enhances the activity at both optima so that the enzyme still exhibits two optima with the maximum stimulation of absolute activity occurring at the acidic maximum. The ATPase from $S$. solfataricus displayed a single $\mathrm{pH}$ optimum located between $\mathrm{pH} 6.5$ and 7.2, regardless of the presence of sulfite, and the maximum sulfite stimulation was of the order of $60 \%$. These and additional differences are summarized in Table III.

Differences also exist among ostensibly similar ATPases from other Archaea. The enzymes from $H$. saccharovorum and $H$. halobium have the same relative molecular masses as do their two major subunits, and both are equally sensitive to nit rate and NBD-Cl. On the other hand, the enzymes differ with respect to their pH optima, detergent activation, and, most significantly, the effect of anions. The enzyme from $H$. saccharovorum is activated by chloride and detergent, whereas the enzyme from $H$. halobium exhibits very little activity in the presence of chloride, is activated by sulfate, sulfite, and citrate, and is unaffected by detergent. In addition, the enzyme from $H$. saccharovorum is unaffected by the nature of the cation, unlike the ATPase from $H$. halobium $(15,17)$. The ATPases isolated from methanogens also appear to differ. The enzyme from $M$. barkeri (30) is composed of two subunits $\left(M_{\mathrm{r}} 62,000\right.$ and 49,000$)$ and is activated by sulfite which causes a shift in the $\mathrm{pH}$ optimum to a more alkaline value. By way of contrast, the ATPase from Methanolobus tindarius is not activated by sulfite and is composed of four subunits whose relative molecular masses are 67,000, $52,000,20,000$, and $<10,000(31)$.

While archael ATPases appear similar, these differences suggest that they may be functionally different enzymes. It should be pointed out that, although ATP syn-
TABLE III

Comparison of the Sulfolobus ATPases

\begin{tabular}{|c|c|c|c|}
\hline Property & $\begin{array}{l}\text { Hochstein and } \\
\text { Stan-Lotter }\end{array}$ & Konishi et al. & Lübben et al. \\
\hline \multicolumn{4}{|l|}{ pH optimum } \\
\hline - Sulfite & $6.5-7.2$ & $5.0 ; 8.5$ & $5.5: 8.0$ \\
\hline+ Sulfite & $6.5-7.2$ & $5.0 ; 8.5$ & $5.5 \cdot 7.0$ \\
\hline \multicolumn{4}{|l|}{ Effect of } \\
\hline Sulfate & Inhibits & Stimulates & Inhibits \\
\hline Chloride & Inhibits & No effect & Stimulates \\
\hline Bicarbonate & No effect & Stimulates & $N R^{d}$ \\
\hline NEM & Inhibits & No effect & $\mathrm{NR}$ \\
\hline Substrate specificity & $A T P=G T P$ & $G T P \gg A T P$ & ATP > G'TP \\
\hline Cation specificity & $\mathbf{M g}=\mathbf{M n}$ & NR & $M_{n}>M_{g}$ \\
\hline
\end{tabular}

- $S$. solfataricus (this study).

'S acidocaldarius (8).

'S. acidocaldarius (18).

${ }^{d} \mathrm{NR}$, not reported.

thesis has been demonstrated in various Archaea $(10,31$, 32 ), there is no direct evidence that such synthesis is caused by any of the archaeal ATPases which have been isolated to date. Whether Archaea synthesize ATP using an enzyme closely related to vacuolar ATPases, an $F_{0} F_{1}$ ATP synthase, or a third type of enzyme has yet to be established.

\section{ACKNOWLEDGMENT}

We acknowledge the technical assistance of Georgette George.

\section{REFERENCES}

1. Bowman, E. J., Sierbers, A., and Altendorf, K. (1988) Proc. Natl Acad. Sci. USA 85, 7972-7976.

2. Fillingame, R. H. (1990) in The Bacteria: A Treatise on Structure and Function (Krulwich, T. A., Ed.), Vol. 12, pp. 345-391, Academic Press, New York.

3. Forgac, M. (1989) Physiol. Rev. 69, 765-796.

4. Nelson, N., and Taiz, L. (1989) Trends Biochem. Sci. 14, 113-116

5. Inatomi, K.-I., Eya, S., Maeda, M., and Futai, M. (1989) J. Biol Chem. 264, 10,954-10,959.

6. Hochstein, L. 1., Kristjansson, H., and Altekar, W. (1987) Biochem Biophys. Res. Commun. 147, 295-300.

7. Schobert, B., and Lanyi, J. K. (1989) J. Biol. Chem. 264, 12,80512,812 .

8. Konishi, J., Wakagi, T., Oshima, T., and Yoshida, M. (1987) J. Biochem. (Tokyo) 102, 1379-1387.

9. Lübben, M., Lünsdorf, H., and Schäfer, G. (1988) Biol Chem. HoppeSeyler 369, 1259-1266.

10. Lübben, M., and Schaefer, G. (1989) J. Bacteriol. 171 , 6106-6116.

11. Denda, K., Konishi, J., Hajiro, K., Oshima, T., Date, T., and Yoshida, M. (1990) J. Biol. Chem. 265, 21,509-21,513.

12. Denda, K., Konishi, J., Oshima, T., Date, T., and Yoshida, M. (1988) J. Biol. Chem. 263, 17,251-17,254.

13. Ihara, K., and Mukohata, Y. (1991) Arch. Biochem. Biophys. 286, $111-116$. 
14. Südhof, T. C., Fried, V. A., Stone, D. K., Johnston, P. A., and Xie, X. S. (1989) Proc. Natl Acad Sci USA 86, 6067-6071.

15. Nanba, T., and Mukohata, Y. (1987) J. Biochem. (Tokyo) 102, 591598.

16. Stan-Lotter, H., Bowman, E. J., and Hochstein, L. I. (1991) Arch. Biochem. Biophys. 284, 116-119.

17. Stan-Lotter, H., and Hochstein, 1. I. (1989) Eur. J. Biochem. 179, 155-160.

18. Lubben, M., Lünsdorf, H., and Sichäfer, G. (1987) Eur. J. Biochem. 167, 211-219.

19. LeBel, D., Poirier, G. G., and Beaudoin, A. R. (1978) Anal Biochem. 85, 86-89.

20. Smith, P. K., Krohn, R. I., Hermanson, G. T., Mallia, A. K., Gartner, F. H., Provenzano, M. D., Fujimoto, E. K., Goeke, N. M., Olson, B. J., and Klend, D. C. (1985) Anal. Biochem. 150, 76-85.

21. Penefsky, H. S. (1977) J. Biol. Chem. 252, 2891-2899.

22. Davis, B. J. (1964) Ann. N. Y. Acad Sci. 121, 404-427.
23. Nimmo, H. G., and Nimmo, G. A. (1982) Anal. Biwchem 121, 17 22.

24. Laemmli, U. K. (1970) Nature (London) 227, 680-685.

25. Means, G. E., and Feenery, R. E. (1971) in Chemical Moditication of Proteins, Holden-Day, San Francisco.

26. Ferguson, S. J., Lloyd, W. J., Lyons, M. H., and Radda, G. K. (1975) Eur. J. Bivchem. 54, 117-126.

27. Kristjansson, H., and Hochstein, L. I. (1985) Arch Biochem. Biophys. 241, 590-595.

28. Arai, H., Berne, M., Terres, G., Terres, H., Puopolo, K., and Forgac, M. (1987) Biochemistry 26, 6632-6638.

29. Bowman, E. J., Mandala, S. L. T., and Bowman, B. J. (1986) Proc Natl. Acad. Sci. USA 83, 48-52.

30. Inatomi, K.-L. (1986) J. Bacteriol. 167, 837-841.

31. Scheel, E., and Schaefer, G. (1990) Eur. J. Biochem. 187, 727-735.

32. Michel, H., and Oesterhelt, D. (1980) Biochemistry 19, 4607-4614. 